\title{
Concentrations of Interleukin-1 13 in Gingival Crevicular Fluid and Saliva - a Potential Diagnostic Biomarker of Periodontal Diseases
}

Theodora Bolyarova-Konova ${ }^{1}$, Silviya Petkova ${ }^{1}$, Hristina Mihaylova ${ }^{2}$, Tsvetelina Velikova ${ }^{3}$, Ekaterina Ivanova-Todorova $^{3}$, Kalina Tumangelova-Yuzeir ${ }^{3}$, Dolores Todorova ${ }^{4}$

${ }^{1}$ Department of Periodontology, Faculty of Dental Medicine, Medical University of Sofia, Sofia, Bulgaria

${ }^{2}$ Department of Imaging and Oral Diagnostics, Faculty of Dental Medicine, Medical University of Sofia, Sofia, Bulgaria

${ }^{3}$ Department of Clinical Laboratory and Clinical Immunology, St Ivan Rilski University Hospital, Medical University of Sofia, Sofia, Bulgaria

${ }^{4}$ Faculty of Dental Medicine, Medical University of Sofia, Sofia, Bulgaria

Corresponding author: Theodora Bolyarova-Konova, Department of Periodontology, Faculty of Dental Medicine, Medical University of Sofia, 1 St George Sofiyski Blvd., Sofia, Bulgaria; E-mail: t_bolyarova@abv.bg; Tel.: +359 887702582

Received: 5 Jan 2020 Accepted: 1 June $2020 \diamond$ Published: 31 Dec 2020

Citation: Bolyarova-Konova T, Petkova S, Mihaylova H, Velikova T, Ivanova-Todorova E, Tumangelova-Yuzeir K, Todorova D. Concentrations of interleukin- $1 \beta$ in gingival crevicular fluid and saliva - a potential diagnostic biomarker of periodontal diseases. Folia Med (Plovdiv) 2020;62(4):825-30. doi: 10.3897/folmed.62.e49872.

\begin{abstract}
Introduction: Bacterial challenge in periodontal diseases activates both local and systemic immune responses of a macroorganism by increasing multiple proinflammatory factors that can be discovered in gingival crevicular fluid (GCF) and in saliva. We tested the hypothesis that IL-1 $\beta$ concentration in GCF and saliva correlates with periodontal health and diseases.

Materials and methods: The study included 62 people (mean age $36 \pm 14 \mathrm{yrs}$ ), divided into three groups - patients with periodontitis (24 people), patients with gingivitis (19 people) and periodontally healthy people (19 people). Saliva and GCF samples were taken from all participants and the levels of IL- $1 \beta$ in all samples were determined by ELISA.

Results: IL-1 $\beta$ concentrations in GCF of healthy individuals were significantly lower than the IL- $1 \beta$ concentration in GCF of patients with gingivitis $(p=0.009)$ and with periodontitis $(p<0.0001)$.

The IL- $1 \beta$ concentrations in the saliva of healthy individuals were significantly lower than the IL-1 $\beta$ concentrations in the saliva of patients with gingivitis $(p=0.002)$ and patients with periodontitis $(p=0.025)$.

Conclusions: Based on the obtained results, IL- $1 \beta$ concentrations in GCF and saliva may be proposed as additional diagnostic criteria of inflammation in periodontal tissues, both at initial diagnosis and at diagnosis of recurrence of periodontitis, but further studies are needed to verify them as markers of periodontal diseases.
\end{abstract}

\section{Keywords}

gingival crevicular fluid, interleukin-1 beta, periodontal diseases, saliva 


\section{INTRODUCTION}

Periodontitis is a chronic multifactorial inflammatory disease associated with dysbiotic plaque biofilms and characterized by progressive destruction of the tooth-supporting apparatus. Its primary features include loss of periodontal tissue support manifested through clinical attachment loss (CAL) and radiographically assessed alveolar bone loss, presence of periodontal pocketing and gingival bleeding. ${ }^{1}$ The prevalence of periodontal disease around the world is reported to vary between $6 \%$ and $50 \% .^{2}$ In modern literature, periodontal diseases are presented as infectious diseases caused by bacterial biofilm attached to the root surface of teeth. ${ }^{3}$ The periodontal lesion is considered a continuously renewing source for systemic spread of bacterial antigens and gram-negative bacteria, which leads to the activation of a local and systemic immune response by the macroorganism, causing the increase of production of multiple proinflammatory factors (cytokines, chemokines, etc.) and mediators of tissue destruction., ${ }^{4,5}$

The conventional methods for periodontal diagnosis most often include measuring of pocket depths, clinical attachment loss, bleeding on probing and x-ray findings of bone loss. These data reflect the severity of the periodontitis and the changes which were caused as a result of the disease's development in the past; however, they cannot rate the disease's activity at the moment of examination. ${ }^{6}$ There is a need to introduce a new diagnostic approach with options to define the changes which are happening at a precise moment in the periodontal complex, to establish disease initiation, to predict the risk of the disease's progression in a certain site and for justifying an individual approach for treatment and monitor the periodontal disease.

Oral liquids - gingival crevicular fluid (GCF) and saliva are used as diagnostic substrates for discovering biomarkers. A biomarker is a substance which is objectively measured and evaluated as an indicator of a normal biological process, a pathological process, or a pharmacological response to a therapeutical intervention. ${ }^{7}$ For now, periodontal biomarkers are not part of the standard diagnostic and treatment process, because of the insufficiency of research in this field. ${ }^{8-10}$ Many case-control, cross-sectional and longitudinal studies have shown that IL-1 $\beta$ in saliva and in GCF increases in periodontal diseases and reflects the progression of periodontal disease. ${ }^{11,12}$ Salivary IL- $1 \beta$ relates in a dose-dependent manner to the severity of the periodontal disease and is reduced after the initial phase of periodontal treatment. ${ }^{13}$ But there are contradictory data - mean salivary levels of IL-1 $\beta$ and others cytokines could not discriminate periodontal health and disease. ${ }^{10}$

In the present study, we tested the hypothesis that IL$1 \beta$ in GCF and IL- $1 \beta$ in saliva correlates with periodontal state - health, gingivitis, and periodontitis.

\section{MATERIALS AND METHODS}

\section{Subject population and study design}

This was a cross-sectional, parallel-group study. The study involved 62 people ( 24 men and 38 women), aged 18 to 75 years (mean age $36 \pm 14$ years) who were admitted for occupational prophylaxis and treatment in the Department of Periodontology at the Faculty of Dental Medicine, Medical University - Sofia. The patients included in the study were over 18 years old, in good general health, had at least 18 teeth in their mouth, and had not received periodontal treatment in the last six months. Patients who had received antibiotics, glucocorticosteroids, inhibitors of cyclooxygenase, and bisphosphonates for less than six months before the study did not participate in the study.

Only subjects who were ambulatory and volunteered to visit the Faculty of Dental Medicine in Sofia were included. The research was ethically conducted according to the Helsinki Declaration of World Medical Association. The Institutional Council on Medical Science of Medical University - Sofia approved the study protocols including the recording of clinical measurements and collection of GCF and saliva samples. All subjects signed informed consent prior to entry into the study.

\section{Clinical exam}

All participants received a clinical periodontal examination, which includes papillary bleeding index (PBI), hygiene index $(\mathrm{HI})$, periodontal pocket depth (PPD), clinical attachment loss (CAL), presence of Furcation defect $(\mathrm{F})$, bleeding on probing (BOP) and orthopantomography. The participants in the study were divided by clinical and radiological criteria into three groups - patients with periodontitis (24 people), patients with gingivitis (19 people) and periodontally healthy people (19 people).

The patients with periodontitis had at least six sites with at least six affected teeth in the six sextants of the dentition with clinical indicators for periodontitis. Each affected site had $P P D \geq 5 \mathrm{~mm}$ and $\mathrm{CAL} \geq 1 \mathrm{~mm}$. BOP $\geq 20 \%$ from all investigated sites in a patient (six sites per tooth) were investigated. Radiological evidence for bone loss was the interdental alveolar crest level's localisation on more than 2 $\mathrm{mm}$ apically from the cementoenamel junction of the teeth ( $2 \mathrm{~mm}$ apically from the cementoenamel junction of the teeth is a normal level). ${ }^{14}$

Patients from the gingivitis group had a $\mathrm{PBI}>30 \%$ from all examined sites which corresponds to a generalized gingivitis and an average value of $\mathrm{PBI}>1$, had $\mathrm{PPD} \leq 4 \mathrm{~mm}$ at every site without any sites with attachment loss, and without any radiologically pronounced bone loss.

The healthy patients had a $\mathrm{PBI} \leq 10 \%$ at all examined sites and the average value of $\mathrm{PBI} \leq 0.1, \mathrm{PPD} \leq 4 \mathrm{~mm}$ at every site, lack of sites with attachment loss, lack of bone loss. 


\section{Saliva samples collection}

Saliva samples were taken from all participants. No interventions were done in the mouth before collecting the saliva sample. Non-stimulated whole saliva was collected in accordance with Navazesh's method ${ }^{15}$ and was modified in accordance with IARC - International Agency for Research on Cancer. (Collecting and Processing Saliva. The Molecular Methods database. Wed, 12/19/2012). Individuals spat into the container at least once a minute for 10 minutes. Around $6 \mathrm{ml}$ of the whole saliva was collected. The containers with saliva were placed in a vessel filled with ice during collection and during the transportation of the material to the laboratory. In the immunologic laboratory, the material was centrifuged at $2600 \times \mathrm{g}$ for 15 minutes at $4^{\circ} \mathrm{C}$. The supernatant was collected in a new cryo tube which contains a solution of lyophilized protease inhibitor (SigmaFast Protease inhibitor, Sigma-Aldrich Co, St. Louis, MO, USA) - 1 $\mu \mathrm{L}$ of a protease inhibitor for every $\mathrm{mL}$ of saliva. All samples were stored in a freezer at temperatures of $-80^{\circ} \mathrm{C}$ until it was time for analysis of the quantity of IL- $1 \beta$ using ELISA (Human IL-1 $\beta$ ELISA, Diaclone, Besancon Cedex, France).

\section{Gingival crevicular fluid samples collection}

During the same visit, but after saliva was collected, GCF from six periodontal sites from every person was also obtained. The predetermined sites had standard parameters that were defined for each clinical group. The collection of GCF was performed using six different microcapillary pipettes (Microcapillary tube, calibrated 1-5 $\mu \mathrm{L}$, Sigma-Aldrich Co, St. Louis, MO, USA) for every patient, after isolating the corresponding section with a lignin roll, drying the surface with a mild stream of air from the dental unit and supragingival plaque removing with a periodontal curette. The microcapillary pipette was placed extracravicularly in contact with the tooth for 5 minutes, without touching the marginal gingival. One $\mu \mathrm{L}$ was required to be collected from each site. The microcapillary pipettes with GCF were immediately transported to the immunological laboratory. The subsequent process included ejection of the exudate in a $1.5 \mathrm{~mL}$ test tube, an addition of a $1 \mathrm{~mL}$ Phosphate buffer solution and freezing in a freezer at $-80^{\circ} \mathrm{C}$ until the moment of the study. The laboratory study includes a quanti- tative determination of IL- $1 \beta$ through the ELISA method (Human IL-1 $\beta$ ELISA, Diaclone, Besancon Cedex, France). No damage or unintended effects of the interventions were expected in each group participants.

\section{Statistical analysis}

Data analysis was performed using relevant medical statistical analyses. The outcome variables evaluated in this study are clinical parameters and mean IL- $1 \beta$ levels in GCF and saliva for each patient. Values for each clinical parameter are averaged across the individual and then averaged among the individuals separately for gingivitis, periodontitis, and periodontally healthy groups. The test of normality (Shapiro-Wilk) of the distributions of immunological parameters in the groups of periodontally healthy, gingivitis and periodontitis showed that the distributions did not appear normal. Therefore, a comparison of the differences in immunological parameters between periodontally healthy, gingivitis and periodontitis was performed using the non-parametric Mann-Whitney U-test. The test compares the mean ranks of a variable in the two groups. A higher average rank in one sample indicates that the observations in that sample tend to have larger values in the population from which the sample was drawn.

The hypothesis tested (the null hypothesis) is that the mean ranks of the variables in the two groups are equal. The null hypothesis is rejected if $p<0.05$.

\section{RESULTS}

All participants in the study groups were included in the analysis (Table 1). The IL-1 $\beta$ concentration in GCF in group of healthy individuals were significantly lower than the IL- $1 \beta$ concentration in GCF in group of patients with gingivitis (Mann-Whitney test, $p=0.009$ ). The IL- $1 \beta$ concentrations in the GCF in group of healthy individuals were significantly lower than the IL- $1 \beta$ concentrations in GCF in group of patients with periodontitis (Mann-Whitney, test $p<0.0001)$. We did not found a significant difference between the IL-1 $\beta$ concentration in GCF in the group of patients with gingivitis and in group of patients with periodontitis (Mann-Whitney test, $p=0.463$ ). The IL- $1 \beta$ concentrations in saliva in the healthy individuals were significant-

Table 1. Concentrations of IL- $1 \beta$ in saliva $(\mathrm{pg} / \mathrm{ml})$ and in GCF $(\mathrm{ng} / \mathrm{ml})$

\begin{tabular}{llll}
\hline & $\begin{array}{l}\text { Healthy periodontium } \\
\mathbf{n = 1 9}\end{array}$ & $\begin{array}{l}\text { Gingivitis } \\
\mathbf{n = 1 9}\end{array}$ & $\begin{array}{l}\text { Periodontitis } \\
\mathbf{n = 2 4}\end{array}$ \\
\hline Range in concentrations of IL-1 $\beta$ in GCF, $\mathrm{ng} / \mathrm{ml}$ & $86.1-2.4=83.7$ & $128.2-7.4=120.8$ & $129.9-7.8=122.1$ \\
Mean IL-1 $\beta$ in GCF, $\mathrm{ng} / \mathrm{ml} \pm \mathrm{SD}$ & $22.1( \pm 20.85)$ & $51.3( \pm 41.61)$ & $58.1( \pm 37.95)$ \\
Median of IL- $1 \beta$ in GCF, ng/ml & 15.4 & 32.2 & 52.4 \\
Range in concentrations of IL-1 $\beta$ in saliva, pg/ml & $487-45=442$ & $491-69=422$ & $491-77=414$ \\
Mean IL- $1 \beta$ in saliva, $\mathrm{pg} / \mathrm{ml} \pm \mathrm{SD}$ & $163( \pm 146)$ & $303( \pm 146)$ & $268( \pm 189)$ \\
Median of $\mathrm{IL}-1 \beta$ in saliva, $\mathrm{pg} / \mathrm{ml}$ & 118 & 305 & 148 \\
\hline
\end{tabular}


ly lower than the IL-1 $\beta$ concentrations in saliva in group of patients with gingivitis (Mann-Whitney test, $p=0.002$ ). The IL- $1 \beta$ concentrations in saliva in group of healthy individuals were significantly lower than the IL- $1 \beta$ concentrations in saliva in the patients with periodontitis (Mann-Whitney test, $p=0.025)$. We did not find a significant difference in the IL- $1 \beta$ concentrations in saliva in the patients with gingivitis and in the patients with periodontitis (Mann-Whitney test, $p=0.434$ ).

Our results show that there are considerable variations of the levels of IL- $1 \beta$ in saliva and IL- $1 \beta$ in GCF in group of people with healthy periodontium, in the group of patients with gingivitis, and in the group of patients with periodontitis.

\section{DISCUSSION}

Gingivitis and periodontitis begin with inflammation of gingival tissue due to bacterial challenge. It is known that IL- $1 \beta$ is a key cytokine in the pathogenesis of periodontal disease; it is produced by many immune cells and mediates the inflammatory response. Elevation of IL- $1 \beta$ level in oral fluid is expected in patients with periodontal disease in accordance with the inflammatory process. Its presence in high concentrations in GCF in patients with periodontitis has been demonstrated. ${ }^{16,17}$ According to some studies, IL$1 \beta$ is one of the markers that differs clearly in its saliva concentrations in patients with periodontitis compared with healthy individuals. ${ }^{13}$ Recent data indicate that IL-1 $\beta$, the macrophage inflammatory protein-1 alpha (MIP-1a), IL-6 and matrix metalloproteinase-8 (MMP-8) are identified as diagnostically acceptable biomarkers for periodontal disease. ${ }^{18}$ There are also studies which do not confirm this finding. In determining the IL- $1 \beta$ concentrations in saliva of patients with periodontitis and in healthy individuals, this interleukin cannot definitively distinguish periodontal health from disease. ${ }^{10,19}$ We found significantly higher mean rank salivary and GCF concentrations of IL- $1 \beta$ in patients with overt periodontitis as well as with gingivitis compared to healthy subjects, confirming its importance in differentiating periodontal health and disease.

A significant correlation has been found in previous studies between concentrations of IL- $1 \beta$ in saliva and the parameters of inflammation in periodontitis, including bleeding on probing. ${ }^{20}$ However, we found no study that establishes different concentrations of IL- $1 \beta$ in GCF or IL- $1 \beta$ in saliva in patients with gingivitis in comparison to those who are healthy. Our results of significantly higher values of IL- $1 \beta$ in GCF and IL- $1 \beta$ in saliva in patients with plaque-induced gingivitis compared with healthy individuals allows us to differentiate the gingival inflammation from health even before periodontal destruction has begun.

Other studies show that salivary levels of IL-1 $\beta$ correlate with the clinical parameters of periodontal disease, such as bleeding on probing, the gingival index, the clinical attachment loss, and the alveolar bone loss. ${ }^{13,20,21}$ The IL- $1 \beta$ levels change with the severity of the disease and decrease significantly after treatment of periodontitis. ${ }^{13,22}$ In our study we did not find a significant difference in the concentrations of IL- $1 \beta$ in GCF and IL- $1 \beta$ in saliva in patients with plaque-induced gingivitis and patients with periodontitis. Based on our results, we cannot propose the parameters IL- $1 \beta$ in GCF and IL- $1 \beta$ in saliva to be regarded as criteria for differentiation of gingivitis and periodontitis. An important result, however, is the significant difference in IL$1 \beta$ concentrations in the studied biological fluids between patients with periodontal health and periodontal disease, which may be useful criteria for differentiation of these conditions.

Similar to other authors ${ }^{13,23}$, our study also identifies large variations in the levels of IL-1 $\beta$ in GCF and IL- $1 \beta$ in saliva in each study group. The independent use of levels of IL- $1 \beta$ in the GCF and IL- $1 \beta$ in saliva is not a sufficiently indicative marker for distinguishing gingivitis and periodontitis, but it is an indicator that can be considered as an additional marker in differentiating periodontal health from periodontal disease.

\section{CONCLUSIONS}

Based on the obtained results, the concentrations of IL- $1 \beta$ in GCF and IL- $1 \beta$ in saliva may be suggested as additional diagnostic criteria for objectifying inflammation in periodontal tissues, both at initial diagnosis and at diagnosis of recurrence of periodontitis, but further studies are needed to verify them as markers of periodontal diseases.

\section{Acknowledgements}

This study was funded by the Medical University of Sofia, under Grant Contract No. 58/27.05.2016 on the topic: Determination of concentrations of certain markers of inflammation and destruction in saliva and gingival exudate for the diagnosis of periodontal diseases.

\section{REFERENCES}

1. Papapanou PN, Sanz M, Buduneli N, et al. Periodontitis: Consensus report of workgroup 2 of the 2017 World Workshop on the classification of periodontal and peri-implant diseases and conditions. J Periodontol 2018;89 Suppl 1:S173-S182.

2. Oliver R, Brown L, Loe H. Variations in the prevalence and extent of periodontitis. J Am Dent Assoc 1991; 122(6):43-8.

3. Darveau R. Periodontitis: a polymicrobial disruption of host homeostasis. Nat Rev Microbiol 2010; 8(7):481-90.

4. Prabhu A, Michalowicz BS, Mathur A. Detection of local and systemic cytokines in adult periodontitis. J Periodontol 1996; 67(5):515-22.

5. Garlet GP. Destructive and protective roles of cytokines in periodontitis: a re-appraisal from host defense and tissue destruction view points. J Dent Res 2010; 89(12):1349-1363. 
6. Armitage G. The complete periodontal examination. Periodontol 2000 2004; 34(1):22-33.

7. Biomarkers Definitions Working Group. Biomarkers and surrogate endpoints: preferred definitions and conceptual framework. Clin Pharmacol Ther 2001; 69(3):89-95.

8. Giannobile WV, Beikler T, Kinney JS, et al. Saliva as a diagnostic tool for periodontal disease: current state and future directions. Periodontol 2000 2009; 50(1):52-64.

9. Sexton WM, Lin Y, Kryscio RJ, et al. Salivary biomarkers of periodontal disease in response to treatment. J Clin Periodontol 2011; 38(5):434-441.

10. Teles RP, Likhari V, Socransky SS, et al. Salivary cytokine levels in subjects with chronic periodontitis and in periodontally healthy individuals: a cross-sectional study. J Periodontal Res 2009; 44(3):411-7.

11. Engebretson SP, Grbic JT, Singer R, et al. GCF IL-1beta profiles in periodontal disease. J Clin Periodontol 2002; 29(1):48-53.

12. Jaedicke KM, Preshaw PM, Taylor JJ. Salivary cytokines as biomarkers of periodontal diseases. Periodontol 2000 2016; 70(1):164-83.

13. Kaushik R, Yeltiwar R, Pushpanshu K. Salivary interleukin-1 $\beta$ levels in patients with chronic periodontitis before and after periodontal phase I therapy and healthy controls: a case-control study. J Periodontol 2011; 82(9):1353-9.

14. Armitage G. Periodontal diagnoses and classification of periodontal diseases. Periodontol 2000 2004; 34(1):9-21.
15. Navazesh M. Methods for collecting saliva. Saliva as a diagnostic fluid. Ann N Y Acad Sci 1993; 694(1):72-7.

16. Buduneli N, Kinane DF. Host-derived diagnostic markers related to soft tissue destruction and bone degradation in periodontitis. J Clin Periodontol 2011; 38(Suppl 11):85-105.

17. Barksby HE, Lea SR, Preshaw PM, et al. The expanding family of interleukin-1 cytokines and their role in destructive inflammatory disorders. Clin Exp Immunol 2007; 149(2): 217-25.

18. Kc S, Wang XZ, Gallagher JE. Diagnostic sensitivity and specificity of host-derived salivary biomarkers in periodontal disease amongst adults: Systematic review. J Clin Periodontol. 2020; 47(3):289-308.

19. Ramseier CA, Kinney JS, Herr AE, et al. Identification of pathogen and host-response markers correlated with periodontal disease. J Periodontol 2009; 80(3): 436-46.

20. Miller CS, King CP Jr, Langub MC, et al. Salivary biomarkers of existing periodontal disease: a cross-sectional study. J Am Dent Assoc 2006; 137(3):322-9.

21. Ng PY, Donley M, Hausmann E, et al. Candidate salivary biomarkers associated with alveolar bone loss: cross-sectional and in vitro studies. FEMS Immunol Med Microbiol 2007; 49(2):252-60.

22. Cheng $\mathrm{R}, \mathrm{Wu} \mathrm{Z}, \mathrm{Li} \mathrm{M}$, et al. Interleukin-1 $\beta$ is a potential therapeutic target for periodontitis: a narrative review. Int J Oral Sci 2020;12(1):2.

23. Ebersole JL, Schuster JL, Stevens J, et al. Patterns of salivary analytes provide diagnostic capacity for distinguishing chronic adult periodontitis from health. J Clin Immunol 2013; 33(1):271-9. 


\section{Концентрация интерлейкина-1ß в жидкости десневой борозды и слюне - потенциальный диагностический биомаркер заболеваний пародонта}

Теодора Болярова-Конова ${ }^{1}$, Силвия Петкова ${ }^{1}$, Христина Михайлова $^{2}$, Цветелина Великова ${ }^{3}$, Екатерина Иванова-Тодорова ${ }^{3}$, Калина Тумангелова-Юзеир ${ }^{3}$, Долорес Тодорова ${ }^{4}$

\footnotetext{
${ }^{1}$ Кафедра пародонтологии, Факультет дентальной медицины, Медицинский университет-София, София, Болгария

${ }^{2}$ Кафедра диагностичной визуализации полости рта, Факультет дентальной медицинь, Медицинский университет - София, София, Болгария

3 Лаборатория клинической иммунологии, УМБАЛ „Св. Иван Рилски“, Медицинский университет - София, София, Болгария.

${ }^{4}$ Факультет дентальной медицинь, Медицинский университет - София, София, Болгария.
}

Адрес для корреспонденции: Теодора Болярова-Конова, Кафедра пародонтологии, Факультет дентальной медицины, Медицинский университет - София, бул. „Георги Софийски“1, София, Болгария; E-mail: t_bolyarova@abv.bg; Тел.: +359 887702582

Дата получения: 5 января 2020 Дата приемки: 1 июня 2020 Дата публикации: 31 декабря 2020

Образец цитирования: Bolyarova-Konova T, Petkova S, Mihaylova H, Velikova T, Ivanova-Todorova E, Tumangelova-Yuzeir K, Todorova D. Concentrations of interleukin- $1 \beta$ in gingival crevicular fluid and saliva - a potential diagnostic biomarker of periodontal diseases. Folia Med (Plovdiv) 2020;62(4):825-30. doi: 10.3897/folmed.62.e49872.

\section{Резюме}

Введение: Бактериальная инфекция при пародонтозе активирует как местные, так и системные иммунные ответы макроорганизма за счёт увеличения количества провоспалительных факторов, которые можно обнаружить в жидкости десневой борозды (ЖДБ) и слюне. Мы предположили, что концентрация IL-1 $\beta$ в желудочно-кишечном тракте и слюне коррелирует со здоровьем и заболеванием пародонта.

Материалы и методы: В исследование включены 62 человека (средний возраст $36 \pm 14$ лет), разделённых на три группы пациенты с пародонтитом (24 человека), пациенты с гингивитом (19 человек) и пародонтально здоровые люди (19 человек). У всех участников были взяты образцы слюны и ЖДБ, и уровни IL-1 $\beta$ во всех образцах были определены с помощью ELISA.

Результаты: Концентрации IL-1 в в желудочно-кишечном тракте здоровых людей были значительно ниже, чем концентрации IL-1 $\beta$ в желудочно-кишечном тракте пациентов с гингивитом ( $=0.009)$ и пародонтитом $(\mathrm{p}<0.0001)$.

Концентрации IL-1 $\beta$ в слюне здоровых людей были значительно ниже, чем концентрации IL-1 $\beta$ в слюне пациентов с гингивитом $(\mathrm{p}=0.002)$ и пациентов с пародонтитом $(\mathrm{p}=0.025)$.

Заключение: На основании полученных результатов концентрации IL-1 $1 \beta$ в ЖДБ и слюне могут быть предложены в качестве дополнительных диагностических критериев воспаления пародонта как при первоначальном диагнозе, так и при диагностике рецидивирующего пародонтита, но для этого необходимы дополнительные исследования, чтобы верифицировать их в качестве маркеров заболеваний пародонта. 